\title{
Hydrogen Peroxide Accumulation and Transcriptional Changes in Grapevines Recovered from Flavescence Dorée Disease
}

\author{
Giorgio Gambino, Paolo Boccacci, Paolo Margaria, Sabrina Palmano, and Ivana Gribaudo
}

First, second, and fifth authors: Plant Virology Institute, National Research Council (IVV-CNR), Grugliasco Unit, Via L. da Vinci 44, 10095 Grugliasco-TO, Italy; and third and fourth authors: Plant Virology Institute, National Research Council (IVV-CNR), Torino, Strada delle Cacce 73, 10135 Torino, Italy.

Accepted for publication 3 March 2013.

\begin{abstract}
Gambino, G., Boccacci, P. Margaria, P., Palmano, S., and Gribaudo, I. 2013. Hydrogen peroxide accumulation and transcriptional changes in grapevines recovered from Flavescence dorée disease. Phytopathology 103:776-784.

Flavescence dorée (FD) is considered one of the most severe phytoplasma diseases affecting grapevine. The spontaneous, complete, and stable remission of the symptoms of FD (recovery) is a phenomenon that may occur in infected grapevines. The molecular bases of this phenomenon are still unclear, although some works suggest that recovery could be linked to the accumulation of hydrogen peroxide $\left(\mathrm{H}_{2} \mathrm{O}_{2}\right)$. Several genes coding for enzymes involved in $\mathrm{H}_{2} \mathrm{O}_{2}$ metabolism, in the ascorbate-gluta-

pression levels of 44 genes were analyzed through quantitative real-time reverse-transcription polymerase chain reaction in healthy $(\mathrm{H})$, infected by FD-associated phytoplasma (I), and 2-years-recovered (R) plants of Vitis vinifera 'Barbera'. In tissues of $\mathrm{R}$ plants, large amounts of $\mathrm{H}_{2} \mathrm{O}_{2}$ were detected, essentially linked to an upregulation of genes involved in the production of $\mathrm{H}_{2} \mathrm{O}_{2}$ (germin-like protein and glycolate oxidase); whereas, in I grapevines, the overexpression of some scavenging genes reduced the quantity of $\mathrm{H}_{2} \mathrm{O}_{2}$. The recovery state was characterized by the activation of ethylene biosynthesis and of defense genes not linked to salicylic acid (SA) signaling, such as the WRKY2 transcription factor. Conversely, I plants reacted to phytoplasma with SA-mediated signaling, even though this response does not appear to be effective against the pathogen.
\end{abstract} thione cycle, defense responses, and the biosynthesis of hormones were identified. The $\mathrm{H}_{2} \mathrm{O}_{2}$ content was biochemically determined and the ex-
Additional keywords: reactive oxygen species.
Phytoplasmas-plant-pathogenic bacteria of the class Mollicutes - infect a wide variety of plants, causing economic losses on cultivated crops worldwide (19). Phytoplasmas are restricted to phloem elements causing a range of disorders, varying from discoloring to plant death, depending on the host, phytoplasma strain, and environmental conditions. In grapevine, phytoplasmas are associated with Grapevine yellows (GYs); among them, Flavescence dorée (FD) and Bois noir (BN) are the most important diseases present in Europe (22). In particular, FD can reach epidemic levels of infection and is subject to quarantine restrictions in Europe, where it represents one of the major threats for the wine industry. In Italy, which is the second wine producer in Europe with its 532 high-quality wines and 48,5 Mhl of production, FD is a serious limiting factor for grape production, particularly in some traditional grapevine growing regions (OIV report) (29). The most frequent symptoms observed on FD-infected grapevines include yellowing or reddening of the leaves according to the variety, curling of the leaves, short internodes, shriveling of the inflorescences and grape berries, and lack of canes lignification. FD diffusion in the vineyards is mainly due to the strictly ampelophagous leafhopper Scaphoideus titanus Ball, which acquires the phytoplasma while feeding in the phloem of infected plants. Phytoplasmas need to not only replicate in the insect body but also pass first the gut and then the salivary gland basal laminae barriers, before being regurgitated into healthy plants along with salivary fluids. The duration of this process is called "retention" or "latent period", and it can last for several weeks. Infected insects remain viruliferous and can transmit phytoplasmas

Corresponding author: G. Gambino; E-mail address: g.gambino@ivv.cnr.it

http://dx.doi.org/10.1094/PHYTO-11-12-0309-R

(C) 2013 The American Phytopathological Society for their entire life (50). Direct control of the insect vector and correct agronomical practices are the main strategy to limit FD infections, due to the absence of genetic sources for resistance. In areas where FD is present, vector control is achieved by compulsory insecticide treatments up to two or three times a year, with a severe environmental impact. It has been reported that phytoplasma-infected grapevines may show a spontaneous and stable remission of symptoms accompanied by the disappearance of the causal agent from the canopy, for which the term "recovery": has been proposed (5). Recovery from phytoplasmas was first reported in woody hosts as apple and apricot $(3,32,33)$ but also in grapevines $(29,37,38)$. In fact, the study of recovery is now of major interest in view of its potential use as a control strategy against phytoplasmas. Different approaches, including microscopic analysis and physiological, transcriptomic, and proteomic studies, have been used to investigate the bases of this interesting phenomenon in apple $(31,32)$, apricot $(33)$, and grapevine for both $\mathrm{BN}(1,18$, $39)$ and FD $(25,30)$. An integrated approach of ultrastructural, cytochemical, and gene-expression analyses showed abnormal callose and phloem-protein accumulation in the leaf phloem of recovered apple trees previously affected by Apple proliferation, together with a remarkable increase of $\mathrm{Ca}^{2+}$ concentration (32). In the same host, a role for hydrogen peroxide $\left(\mathrm{H}_{2} \mathrm{O}_{2}\right)$ in the recovery phenomenon has been proposed, and further supported by analyses in apricot (33) and grapevine (30). Musetti et al. (30) suggested that recovered plants likely accumulate $\mathrm{H}_{2} \mathrm{O}_{2}$ because of the stable downregulation of two genes coding for main enzymatic $\mathrm{H}_{2} \mathrm{O}_{2}$ scavengers: namely, catalase and ascorbate peroxidase. A proteomic analysis of recovered 'Barbera' grapevines confirmed downregulation of ascorbate peroxidase protein (25), supporting the link between recovery and accumulation of $\mathrm{H}_{2} \mathrm{O}_{2}$.

$\mathrm{H}_{2} \mathrm{O}_{2}$, as well as the superoxide radical $\left(\mathrm{O}_{2}^{-}\right)$and hydroxyl radical $(\mathrm{OH})$, are reactive oxygen species (ROS) that in plants are 
induced by several abiotic and biotic stresses. ROS are highly reactive to membrane lipids, proteins and DNA, and act as secondary messengers in several physiological processes (9). ROS are generated via electron transport reactions in both mitochondria and chloroplasts, and via several enzyme-mediated reactions (41). The excess of ROS accumulation can lead to oxidative stress, which then triggers plant cell death (PCD) and, consequently, requires the intervention of antioxidant systems in the cells. Scavenging enzymes, including catalase (CAT), peroxidase (POX), superoxide dismutase (SOD), ascorbate peroxidase (APX), and glutathione peroxidase (GPX), and nonenzymatic antioxidants such as ascorbic acid (AsA) and reduced glutathione (GSH), work in concert to detoxify ROS (9). AsA eliminates $\mathrm{H}_{2} \mathrm{O}_{2}$ through APX activity or directly; in the latter case, it needs a regeneration system in which monodehydroascorbate reductase (MDHAR), dehydroascorbate reductase (DHAR), glutathione reductase (GR), and GSH are involved. In addition to antioxidant functions, GSH is a substrate for glutathione S-transferase (GST), a large family of proteins that catalyze the conjugation of GSH to various electrophilic substrates, preventing the oxidative stress arising from the generation of potentially toxic endogenous metabolites (35).

The ROS production following pathogen attacks acts as an essential component in the signal transduction cascade leading to defense responses. ROS interacts with a network of signal transduction pathways for resistance induction in which the small molecules salicylic acid (SA), jasmonic acid (JA), and ethylene (ET) act as secondary messengers, resulting in the activation of distinct sets of defense-related genes (43). It is commonly accepted that SA promotes resistance against biotrophic pathogens, whereas JA and ET act as positive signals against necrotrophic ones (13). The interaction between SA and JA/ET generally acts in antagonistic pathways inducing differential expression patterns of defense genes, such as pathogenesis-related (PR) genes, although synergistic actions of SA and JA/ET have been reported (44). SA accumulation and the coordinated expression of PR genes are necessary for the onset of systemic acquired resistance (SAR) in plants (13).

In the present work, we investigated some molecular aspects of the grapevine-Flavescence dorée phytoplasma (FDp) relationship in infected and recovered plants of Vitis vinifera Barbera, a cultivar highly susceptible to FD. In addition to expression analysis of several genes involved in production and scavenging of $\mathrm{H}_{2} \mathrm{O}_{2}$, we focused on transcript changes of genes involved in defense responses and hormone metabolism.

\section{MATERIALS AND METHODS}

Plant materials. The study was carried out in a vineyard in Cocconato (Piemonte), northwest Italy, on the red grape 'Barbera' (V. vinifera L.). The vineyard had been monitored since 2008 for phytoplasma infection, and a map of FDp-infected (I), recovered (R) (i.e., plants found positive for FDp in the past but FDpnegative and symptomless for the last 2 years), and healthy $(\mathrm{H})$ plants was already available at the beginning of the study. The FDp isolate present in the vineyard had been characterized following the methods described by Martini et al. (28) and Angelini et al. (2) and belonged to the $16 \mathrm{SrV}-\mathrm{C}$ subgroup.

Phytoplasma (FDp and Bois noir phytoplasma [BNp]) infection was monitored following a previously established protocol (27), and virus infection was determined by multiplex reversetranscription polymerase chain reaction (RT-PCR) (11) to detect nine viruses that commonly infect grapevine in Italy and in other viticultural countries: Arabis mosaic virus, Grapevine fanleaf virus, Grapevine virus B, Grapevine fleck virus, Grapevine leafroll associated virus-1, -2, and -3, Grapevine virus A, and Grapevine rupestris stem pitting-associated virus (GRSPaV).

Samples were collected in the vineyard on 8 September 2011, when the disease was evident and typical symptoms of infection were clear on infected plants. Six plants from each thesis $(H, R$, and I) were selected, and three basal and three apical leaves of approximately the same age were collected from each plant. All sampled plants had the same age. Particular attention was kept on selection of diseased plants (I): all of them were severely infected and showed comparable symptoms associated with advanced disease, distributed all over the plant, including complete reddening of the leaves, triangular leaves exhibiting leaf rolling, withering of inflorescences and grape berries, and lacking or irregular shoot lignification. In I plants, only canes showing all the symptoms reported were chosen for sampling, and infected tissues with advanced necrotic areas were excluded. In $\mathrm{R}$ and $\mathrm{H}$ plants, leaves were randomly collected in different canes for each plant. The six plants selected for each thesis were divided into two groups of three plants each, thus giving two independent biological replicates; leaf midribs were cut with a scalpel and used for real-time quantitative (q)RT-PCR and $\mathrm{H}_{2} \mathrm{O}_{2}$ quantification.

Database analyses and target gene identification. The putative sequences of genes of interest were retrieved from the two available draft genome sequences of grapevine (PN40024: http:// www.genoscope.cns.fr/externe/GenomeBrowser/Vitis/ [17] and 'Pinot Noir' ENTAV115: http://genomics.research.iasma.it/gb2/ gbrowse/grape [46]) and the National Centre for Biotechnology Information database (http://www.ncbi.nlm.nih.gov/) using Arabidopsis proteins sequences as the search term (Table 1).

We searched for the DNA sequences coding for enzymes involved in $\mathrm{H}_{2} \mathrm{O}_{2}$ production (glycolate oxidase [GOX], germinlike protein [GLP], acyl CoA oxidase [ACX], and NADPH oxidase $[\mathrm{NOX}]$ ), in $\mathrm{H}_{2} \mathrm{O}_{2}$ scavenging (CAT, POX, SOD, APX, and GPX), in the AsA-GSH cycle (MDHAR, DHAR, GR, and GST), and in the GSH biosynthesis (glutamylcysteine synthetase [ $\gamma$ ECS] and glutathione synthetase [GSH-S]). Among the genes involved in disease resistance we identified sequences for PR-1, PR-10, thaumatin-like protein (THAU), $\beta-1-3$ glucanase (BGL), nonexpressor of PR-1 gene (NPR1), and WRKY transcription factors. In addition, genes responsible for biosynthesis of abscisic acid (ABA), 9-cis-epoxycarotenoid dioxygenase (NCED), ET, 1-aminocyclopropane-1-carboxylate oxidase (ACO), JA, and 12-oxophytodienoate reductase 2-like (OPR) were also retrieved.

Determination of $\mathrm{H}_{2} \mathrm{O}_{2}$ content. $\mathrm{H}_{2} \mathrm{O}_{2}$ was quantified in $\mathrm{H}$, R, and I grapevines by a peroxidase-coupled assay (3-dimethylaminobenzoic acid [DMAB]-3-methyl-2-benzothiazolinone hydrazone [MBTH]-POX method), as previously reported by Veljovic-Jovanovic et al. (47). In brief, leaf midribs were ground in liquid nitrogen and the powder extracted in $1 \mathrm{M} \mathrm{HClO}_{4}(1 \mathrm{ml}$ for $100 \mathrm{mg}$ of tissues) in the presence of 5\% insoluble polyvinylpolypyrrolidone. The samples were centrifuged at $12,000 \times g$ for $10 \mathrm{~min}$ and incubated for $10 \mathrm{~min}$ with $1 \mathrm{U}$ of ascorbate oxidase. The supernatant was adjusted to $\mathrm{pH} 5.6$ with $5 \mathrm{M} \mathrm{K}_{2} \mathrm{CO}_{3}$ and centrifuged at $12,000 \times g$ for $1 \mathrm{~min}$ to remove $\mathrm{KClO}_{4}$. The reaction mixture consisted of $0.1 \mathrm{M}$ phosphate buffer $(\mathrm{pH} 6.5), 3.3 \mathrm{mM}$ DMAB, $0.07 \mathrm{mM} \mathrm{MBTH}$, and $50 \mathrm{ng}$ of POX (Sigma-Aldrich, St. Louis, MO). The absorbance changes at $590 \mathrm{~nm}$ were monitored at $25^{\circ} \mathrm{C}, 10 \mathrm{~min}$ after the addition of $100 \mu \mathrm{l}$ of samples to the reaction mixture. The $\mathrm{H}_{2} \mathrm{O}_{2}$ contents were determined by a calibration curve using known amounts of $\mathrm{H}_{2} \mathrm{O}_{2}$ and expressed as nanomoles per gram of fresh weight $(\mathrm{FW})$. The $\mathrm{H}_{2} \mathrm{O}_{2}$ contents were calculated over three technical replicates for each biological replicate (in total, six replicates for each thesis). Data were statistically analyzed by applying the analysis of variance (ANOVA) $F$ test.

Relative real-time qRT-PCR. Total RNA was extracted from leaf midribs following the protocol previously described (12). Primers were designed using the software Primer Express 3.0 (Applied Biosystems Life Technologies, Carlsbad, CA) (Table 1), and first-strand cDNA synthesis was performed using $5 \mu \mathrm{g}$ of total RNA treated with DNase (Invitrogen Life Technologies, Carlsbad, CA) and the High Capacity cDNA Reverse Transcrip- 
tion kit (Applied Biosystems Life Technologies). The relative expression was computed as previously described (10) using the geometric mean of the expression ratios of two housekeeping genes (actin and ubiquitin) as the normalization factor in all samples. The PCR reaction mix $(10 \mu \mathrm{l})$ contained $5 \mu \mathrm{l}$ of PowerSYBR Green master mix (Applied Biosystems Life Technologies), $0.25 \mu \mathrm{M}$ each primer (Table 1 ), and $1 \mu \mathrm{l}$ of cDNA diluted 1:10. Cycling conditions for all primer pairs consisted of initial denaturation at $95^{\circ} \mathrm{C}$ for $10 \mathrm{~min}$ followed by 40 cycles at $95^{\circ} \mathrm{C}$ for $15 \mathrm{~s}$ and $60^{\circ} \mathrm{C}$ for $1 \mathrm{~min}$. qRT-PCR was performed in triplicate and specific annealing of the primers was controlled on dissociation kinetics performed at the end of each qRT-PCR run. Transcript level was expressed as the mean and standard error calculated over three technical replicates for each biological replicate (in total, six replicates for each thesis). Data were statistically analyzed by applying the ANOVA $F$ test.

\section{RESULTS}

Sanitary status of grapevines and database analysis. During the preliminary phase of the work in 2011, six plants showing GY symptoms and infected by FDp (I), six plants recovered (R) for 2 years, and six healthy grapevines $(\mathrm{H})$ which had always tested negative for FDp were identified in the vineyard. All plants were negative for $\mathrm{BNp}$ and, in all of them, $\mathrm{GRSPaV}$, a widespread virus infecting grapevine, was present.

The two available draft genome sequences of grapevine $(17,46)$ were screened using Arabidopsis sequences as the search term in order to find the homologue Vitis genes. More than 150 nonredundant potential gene sequences were identified in grapevine coding for 15 enzymes involved in $\mathrm{H}_{2} \mathrm{O}_{2}$ production (GOX, GLP, ACX, and $\mathrm{NOX}$ ), $\mathrm{H}_{2} \mathrm{O}_{2}$ scavenging (SOD, GPX, APX, CAT, and POX), and the AsA-GSH cycle (GR, MDHAR, DHAR, GST, $\gamma$-ECS, and GSH-S); and for nine proteins involved in defense responses (PR-1, PR-10, NPR1, WRKY, THAU, and BGL) and hormone metabolism (NCED, ACO, and OPR). One to four genes potentially coding for each enzyme were chosen and analyzed, according to literature data when available for grapevine and to sequence homology with proteins already characterized in Arabidopsis (Table 1).

Gene expression changes monitored in recovered and FDpinfected grapevines. The peroxidase-coupled assay detected a greater amount of $\mathrm{H}_{2} \mathrm{O}_{2}$ in leaf midribs of $\mathrm{R}$ plants in comparison with $\mathrm{H}$ and I grapevines (Fig. 1). Accordingly, transcript analysis in $\mathrm{R}$ samples showed a strong upregulation of genes involved in the production of $\mathrm{H}_{2} \mathrm{O}_{2}$ (Fig. 2). In particular, GOX and GLP1 were at least fourfold more expressed in $\mathrm{R}$ plants than in $\mathrm{H}$ and $\mathrm{I}$ plants, and a significant difference was also observed for $G L P 3$, $A C X 1$, and $A C X 2$ transcripts. The expression levels of all these

TABLE 1. Genes chosen on the basis of database analyses and oligonucleotides used in quantitative reverse-transcription polymerase chain reaction experiments

\begin{tabular}{|c|c|c|c|c|c|}
\hline \multicolumn{2}{|c|}{ NCBI accession number ${ }^{a}$} & \multirow[b]{2}{*}{ Gene description } & \multirow[b]{2}{*}{ Primer } & \multirow[b]{2}{*}{ Primer sequences $5^{\prime}-3^{\prime}$} & \multirow[b]{2}{*}{ References } \\
\hline Grapevine & Arabidopsis & & & & \\
\hline \multirow[t]{2}{*}{ XM_002278068 } & NM_112302 & Glycolate oxidase (GOX) & Forward & GTGGTTGCCGCTCCCTTA & This study \\
\hline & & & Reverse & AGCGTCCCAGTCAGTCATGAT & \\
\hline \multirow[t]{2}{*}{ EF064171 } & NM_117545 & Germin-like protein (GLP1) & Forward & AAGAATGCTGTGTTTGTAAATGGAAA & 14 \\
\hline & & & Reverse & TCGGCGACGGTCAGGTT & \\
\hline \multirow[t]{2}{*}{ AY298727 } & NM_123272 & Germin-like protein (GLP3) & Forward & AGCAAATGCAGTCTTTGGATCA & 8 \\
\hline & & & Reverse & GGCCCTGGTGAGAACATCA & \\
\hline \multirow[t]{2}{*}{ XM_002269107 } & NM_001203815 & Acyl CoA Oxidase (ACX1) & Forward & TGTGGTGGCCATGGTTACC & This study \\
\hline & & & Reverse & GGGACATACACGGCAAATAACTC & \\
\hline \multirow[t]{2}{*}{ XM_002278627 } & NM_100511 & Acyl CoA Oxidase (ACX2) & Forward & TTGGGCAAATGAAAGGTGAAT & This study \\
\hline & & & Reverse & GAACGTTGTTGTCACCCTCAAA & \\
\hline \multirow[t]{2}{*}{ XM_002268568 } & NM_124165 & NADPH oxidase (NOX1) & Forward & СТCCTTGTTCTGCGAATGCA & This study \\
\hline & & & Reverse & GCTCACCGGCGAATTCCT & \\
\hline \multirow[t]{2}{*}{ XM_002282260 } & NM_124485 & NADPH oxidase (NOX3) & Forward & TCACGCCAAGAAGGGCTATG & This study \\
\hline & & & Reverse & TTGCCGAAGTGGGACTTGA & \\
\hline \multirow[t]{2}{*}{ XM_002283852 } & NM_202070 & NADPH oxidase (NOX5) & Forward & CAGGGCGGAGTTGAGAGAGTT & This study \\
\hline & & & Reverse & CCTGGCATCGAAGCTTTGAT & \\
\hline \multirow[t]{2}{*}{ XM_002280486 } & NM_124489 & Superoxide dismutase (SOD1) & Forward & TGATCTCCTTCCAGCCTTCAA & 48 \\
\hline & & & Reverse & TCCCAGAAGGAGGTGTGGTT & \\
\hline \multirow[t]{2}{*}{ XM_002274385 } & NM_001125773 & Superoxide dismutase (SOD2) & Forward & GGGAACCTCCTCCGTTGAAG & 4,18 \\
\hline & & & Reverse & CAGTCGTTGGGCCATCGT & \\
\hline \multirow[t]{2}{*}{ XM_002280491 } & NM_111929 & Superoxide dismutase (SOD3) & Forward & GGCGATTCATCTACGGTTGTC & 48 \\
\hline & & & Reverse & CCTCCGCCGTTGAACTTG & \\
\hline \multirow[t]{2}{*}{ XM_002276220 } & NM_116173 & Glutathione peroxidase (GPX1) & Forward & CGCTATGGCCCAACAACTG & 45 \\
\hline & & & Reverse & ACTTGTCTCCCAAGGCTTTCTG & \\
\hline \multirow[t]{2}{*}{ XM_002272570 } & AF030132 & Glutathione peroxidase (GPX2) & Forward & CGTTTATTCGCCACGTGTGA & 48 \\
\hline & & & Reverse & GACGAATAACTGGAAACCCCTTAC & \\
\hline \multirow[t]{2}{*}{ XM_002284731 } & NM_001123772 & Ascorbate peroxidase (APX1) & Forward & AGGCCTCATCGCTGAGAAGA & 48 \\
\hline & & & Reverse & GCAGAGTGCCATGCGATTC & \\
\hline \multirow[t]{2}{*}{ EU280159 } & NM_111798 & Ascorbate peroxidase (APX2) & Forward & GAGGGTTCATCGCTGAGAAGA & This study \\
\hline & & & Reverse & GCGGAGTGCCATGCTAGTC & \\
\hline \multirow[t]{2}{*}{ XM_002278245 } & NM_119666 & Ascorbate peroxidase (APX3) & Forward & CCCAATCCCCAGACCAATC & This study \\
\hline & & & Reverse & TCGGCGTCTGCTGAGCTT & \\
\hline \multirow[t]{2}{*}{ XM_002282641 } & NM_119384 & Ascorbate peroxidase (APX6) & Forward & GCCCACTCTCCCCATTCTC & This study \\
\hline & & & Reverse & TGGAGTTTTGGCGGGAAAT & \\
\hline \multirow[t]{2}{*}{ XM_002270667 } & NM_101914 & Catalase (CAT1) & Forward & CGCCCTTCGAGTGCTTACA & 48 \\
\hline & & & Reverse & CAGGAGCACCGGAATTGG & \\
\hline \multirow[t]{2}{*}{ XM_002263922 } & NM_119675 & Catalase (CAT2) & Forward & GGACAGGCAAGAGCGTTTCA & 48 \\
\hline & & & Reverse & GGTGACCCTTGGATCAGACAA & \\
\hline XM_002269882 & NM_120616 & Peroxidase (POX4) & Forward & TGGCTGCGATGCATCAGT & This study \\
\hline & & & Reverse & CTGCTCGCCAGTGAAGGAA & \\
\hline XM_002269761 & NM_123583 & Peroxidase (POX5) & Forward & GTTCGCATTGCAGTTCCTTCA & This study \\
\hline & & & Reverse & CCTGGCCCGATGTTCCA & \\
\hline
\end{tabular}

a NCBI = National Center for Biotechnology Information. 
genes, together with $N O X 1$ and $N O X 5$, were not significantly different between $\mathrm{H}$ and I tissues. In contrast, the NOX3 transcripts were upregulated in I plants in comparison with $\mathrm{H}$ plants but neither were significantly different compared with $\mathrm{R}$ tissues.

Concerning the genes coding for scavenging enzymes, no significant difference was detected in transcript abundances of $S O D 1, G P X 1, G P X 2$, and $A P X 1$ within the three groups studied. In contrast, SOD2, SOD3, APX2, POX4, and POX5 were upregulated in I compared with $\mathrm{H}$ tissues, and transcripts of $A P X 3$, $A P X 6$, and $C A T 1$ were upregulated in $\mathrm{R}$ compared with $\mathrm{H}$ plants (Fig. 3). In addition, scavenging genes were generally less or equally expressed (with the exception of $A P X 2$ and $A P X 6$ ) in $\mathrm{H}$ plants compared with $\mathrm{R}$ and I tissues, where a high variability in gene expression levels was detected (Fig. 3).

The transcription level of several genes involved in glutathione metabolism did not appear to be strongly influenced by FDp and few differences in gene expression were detected: GST2 was upregulated in R plants, while $\gamma-E C S$ and $G S H-S$, the last and most important genes responsible for GSH synthesis, were upregulated in I and R plants, respectively (Fig. 4).

Accumulation imbalance and removal of $\mathrm{H}_{2} \mathrm{O}_{2}$ observed in $\mathrm{R}$ plants did not induce an extensive modulation of genes involved in defense response. In fact, defense-related genes, such as PR genes (PR-1, BGL2, and THAU1) involved in SA-mediated resistance, were significantly upregulated only in I plants (Fig. 5). NPR1.1 and NPR1.2 transcripts, positive regulators of the SA-

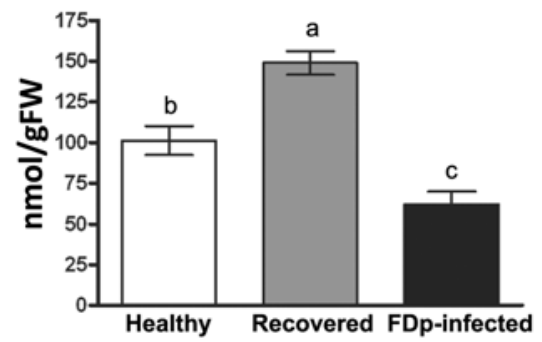

Fig. 1. Hydrogen peroxide $\left(\mathrm{H}_{2} \mathrm{O}_{2}\right)$ quantification by a peroxidase-coupled assay (3-dimethylaminobenzoic acid 3-methyl-2-benzothiazolinone hydrazine peroxidase method). The $\mathrm{H}_{2} \mathrm{O}_{2}$ contents are expressed as nanomoles per gram of fresh weight $(\mathrm{FW})$ of leaf midribs collected from healthy $(\mathrm{H})$, recovered $(\mathrm{R})$, and Flavescence dorée phytoplasma (FDp)-infected (I) 'Barbera' grapevines. Data are presented as mean \pm standard error of two biological and three technical replicates $(n=6)$; different letters denote significant differences at $P \leq 0.05$.

TABLE 1. (continued from preceding page)

\begin{tabular}{|c|c|c|c|c|c|}
\hline \multicolumn{2}{|c|}{ NCBI accession number ${ }^{a}$} & \multirow[b]{2}{*}{ Gene description } & \multirow[b]{2}{*}{ Primer } & \multirow[b]{2}{*}{ Primer sequences $5^{\prime}-3^{\prime}$} & \multirow[b]{2}{*}{ References } \\
\hline Grapevine & Arabidopsis & & & & \\
\hline \multirow[t]{2}{*}{ AF019907 } & \multirow[t]{2}{*}{ NM_115323 } & \multirow[t]{2}{*}{ Glutathione reductase (GR1) } & Forward & AATATGGCTGCGGCAACCT & \multirow[t]{2}{*}{45} \\
\hline & & & Reverse & TGAAGCTTTGGAGAAGAGAATGTG & \\
\hline \multirow[t]{2}{*}{ XM_002285636 } & \multirow[t]{2}{*}{ NM_001125216 } & \multirow[t]{2}{*}{ Glutathione reductase (GR2) } & Forward & TCCAGGGCAGGAGTTGTCTATT & \multirow[t]{2}{*}{4} \\
\hline & & & Reverse & GCTTGGGCAACTCATCCAA & \\
\hline \multirow[t]{2}{*}{ XM_002277164 } & \multirow[t]{2}{*}{ NM_113698 } & \multirow[t]{2}{*}{ Monodehydroascorbate reductase (MDHAR1) } & Forward & TGGAATTGAACTGGTCCTTGGT & \multirow[t]{2}{*}{ This study } \\
\hline & & & Reverse & GCGTCTTCCGCCTCACAT & \\
\hline \multirow[t]{2}{*}{ EF554360 } & \multirow[t]{2}{*}{ NM_001161202 } & \multirow[t]{2}{*}{ Monodehydroascorbate reductase (MDHAR2) } & Forward & CGGCGGTGGCGTTTC & \multirow[t]{2}{*}{ This study } \\
\hline & & & Reverse & ACCCCTTGCTTGGCAAACT & \\
\hline \multirow[t]{2}{*}{ XM_002282363 } & AY074785 & Dehydroascorbate reductase (DHAR1) & Forward & CTCGGGAGTCCTTTGAGAAAAC & This study \\
\hline & & & Reverse & GTGCCCATCCTGCAACTACA & \\
\hline XM_002266070 & NM_121676 & Dehydroascorbate reductase (DHAR2) & Forward & GAGGAGAGCAAAGGGCAATG & This study \\
\hline & & & Reverse & GGACGAAACAGCCGAAGCT & \\
\hline XM_002264667 & NM_114248 & Glutathione S-transferase (GST1) & Forward & GGTTTGGAAGGATAGATGTCGTCTT & 45 \\
\hline & & & Reverse & AACTTGGCTTTTGCTCTTTGGT & \\
\hline EF088687 & NM_180148 & Glutathione S-transferase (GST2) & Forward & TGATAAAATTCGATTTGCGGAAT & 45 \\
\hline & & & Reverse & TCCGTCTTCAAAGGCTGGAA & \\
\hline FQ383287 & NM_001203879 & Glutamylcysteine synthetase $(\gamma$-ECS) & Forward & TGGAGGCGTCTAAAATAAAGGAA & 45 \\
\hline & & & Reverse & TGTGCGGCTCCTTGATAGTG & \\
\hline XM_002284915 & NM_122620 & Glutathione synthetase (GSH-S) & Forward & GGGCTTGTTGTTGGCGATAG & This study \\
\hline & & & Reverse & CCATGCCCACACCAGGAA & \\
\hline XM_002273380 & NM_103894 & Pathogenesis-related protein $1(\mathrm{PR}-1)$ & Forward & ACAATACTGCTCGGGCACAAG & 21 \\
\hline & & & Reverse & AGAGGCTACGGTGTTGTTCCA & \\
\hline XM_003635446 & & $\beta$ 1-3 glucanase (BGL1) & Forward & AGGAAGAACGACGATCGAAATC & 10 \\
\hline & & & Reverse & TGGAGGAAGAGGCCATTTGA & \\
\hline XM_002277133 & NM_115587 & $\beta$ 1-3 glucanase (BGL2) & Forward & GCAGTCGGGAACGAAGTGA & 10 \\
\hline & & & Reverse & ACTGCGCAAACCGTGATGT & \\
\hline AF227324 & & Thaumatin-like protein (THAU1) & Forward & CGCTGAATTCGCTCTAAACCA & 26 \\
\hline & & & Reverse & AGCCATCGACAAGGGAGATG & \\
\hline XM_002282928 & & Thaumatin-like protein (THAU2) & Forward & ACСССАСТССААСCATCAAG & 26 \\
\hline & & & Reverse & GATTTTGCAGAGGCCCATTG & \\
\hline XM_002281439 & HQ845963 & Nonexpressor of PR-1 genes (NPR1.1) & Forward & TGATATCACGCCAGACGGTAGA & 20 \\
\hline & & & Reverse & CAGCCCTGGTGAGCCTCTT & \\
\hline XM_003633009 & NM_123879 & Nonexpressor of PR-1 genes (NPR1.2) & Forward & TGGCATTTGCACGATTATTCTT & 20 \\
\hline & & & Reverse & TCAGCATGCGCTATCTCCAT & \\
\hline AJ291705 & & Pathogenesis-related protein 10 (PR-10) & Forward & GTTCCCCCAGCCAAGATGT & 45 \\
\hline & & & Reverse & TTGGGAATGAGGTTGTCAGAATC & \\
\hline XM_002283836 & NM_121311 & WRKY1 & Forward & AGGTAAAAAGGAAGGTCAAAAGAAGA & 24 \\
\hline & & & Reverse & AACATGGCTCCTCGTTTGAAA & \\
\hline XM_002264207 & NM_101262 & WRKY2 & Forward & GCCCATTCCCATATGCAACT & 34 \\
\hline & & & Reverse & CGGGTGCCACTGATAAAGAAG & \\
\hline XM_002270125 & NM_118036 & 9-cis-epoxycarotenoid dioxygenase (NCED) & Forward & GCCCCAACCCCCAGTTC & 10 \\
\hline & & & Reverse & GCATGCCATCACCATCAAAG & \\
\hline XM_002273394 & NM_104918 & 1-aminocyclopropane-1-carboxylate oxidase & & & \\
\hline & & $(\mathrm{ACO})$ & Forward & GTGGGCTTCAGCTCCTCAAG & 10 \\
\hline & & & Reverse & GAGTGTCGCATCGGTGGAA & \\
\hline XM_002277985 & NM_106319 & 12-oxophytodienoate reductase 2-like (OPR) & Forward & TGTTGTGTATGGGCGTTGGT & 10 \\
\hline & & & Reverse & GAGCGCAAATCTCTTTGGAAGA & \\
\hline
\end{tabular}


dependent signaling pathway, were not significantly modulated in any group, while $W R K Y 1$ and $W R K Y 2$ transcription factors were upregulated in I and $\mathrm{R}$ plants, respectively. In I, the transcript levels of $P R-10$ (with ribonuclease activity) were $50 \%$ lower than in $\mathrm{H}$ and $\mathrm{R}$ plants.

Among the genes associated with hormone signaling, NCED was strongly activated in I tissues (the gene was at least 25-fold more expressed than in $\mathrm{H}$ and $\mathrm{R}$ plants), whereas no difference was observed between $\mathrm{H}$ and $\mathrm{R}$. In contrast, in $\mathrm{R}$ grapevines, $A C O$ was threefold more expressed than in I leaves, which also showed repression compared with $\mathrm{H}$ tissues. $O P R$ transcripts were significantly downregulated in both $\mathrm{R}$ and $\mathrm{I}$ in comparison with $\mathrm{H}$ plants (Fig. 5).

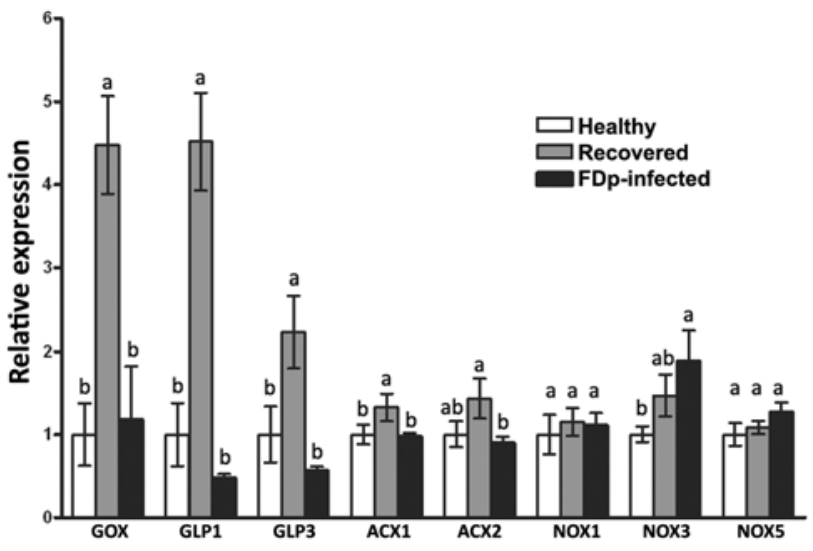

Fig. 2. Relative expression level of genes involved in the production of hydrogen peroxide $\left(\mathrm{H}_{2} \mathrm{O}_{2}\right)$ : glycolate oxidase $(G O X)$, germin-like protein $(G L P)$, acyl CoA oxidase $(A C X)$, and NADPH oxidase $(N O X)$ in healthy $(\mathrm{H})$, recovered (R), and Flavescence dorée phytoplasma (FDp)-infected (I) 'Barbera' leaf midribs as determined by quantitative reverse-transcription polymerase chain reaction. Data are presented as mean \pm standard error of two biological and three technical replicates $(n=6)$; for each gene, different letters denote significant differences at $P \leq 0.05$.

\section{DISCUSSION}

Molecular relationships between FDp and grapevine are still poorly understood, and the mechanisms involved in the recovery phenomenon have not been completely elucidated. In recent years, the accumulation of $\mathrm{H}_{2} \mathrm{O}_{2}$ has been associated with the recovery from phytoplasma-associated diseases $(30,32,33)$. Variations in the oxidative status in the phloem of recovered plants might activate some defense responses resulting in or contributing to spontaneous remission of FD symptoms and disappearance of the pathogen. In order to test this hypothesis, we studied the expression levels of genes involved in the metabolism of $\mathrm{H}_{2} \mathrm{O}_{2}$, in healthy, recovered, and FDp-infected 'Barbera' plants, as well as the expression changes of genes linked to defense response and hormone biosynthesis.

$\mathrm{H}_{2} \mathrm{O}_{2}$ metabolism in FDp-recovered grapevines. Previous experience proved that it is difficult to maintain FDp infection in potted grapevine plants for a long period of time (I. Gribaudo, G. Gambino, and F. Mannini, unpublished data). Conversely, field conditions can result in large environmental variability that might affect experimental results. The plant materials used in this study were collected from vines cultivated in a commercial vineyard but, in order to minimize the potential variability, the plants belonged to the same 'Barbera' clone and were grown at a minimum distance in the vineyard. Furthermore, to check the sanitary status of the plant material, each plant was assayed for the presence of nine viruses commonly infecting grapevine. In all plants, we detected GRSPaV only, a widespread virus infecting grapevine that establishes a compatible viral interaction in $V$. vinifera. Although it has been recently reported that GRSPaV induces transcriptomic alterations in grapevine (10), because all plants used in these analyses were infected by this virus, its presence might not have biased the results.

In leaf midribs of $\mathrm{R}$ plants, a larger amount of $\mathrm{H}_{2} \mathrm{O}_{2}$ was detected in comparison with $\mathrm{H}$ and I plants. The same results were previously reported by Musetti et al. (30), who identified $\mathrm{H}_{2} \mathrm{O}_{2}$ through transmission electron microscopy in the plasmalemma of the sieve tube in recovered plants only. However, using a chromo-

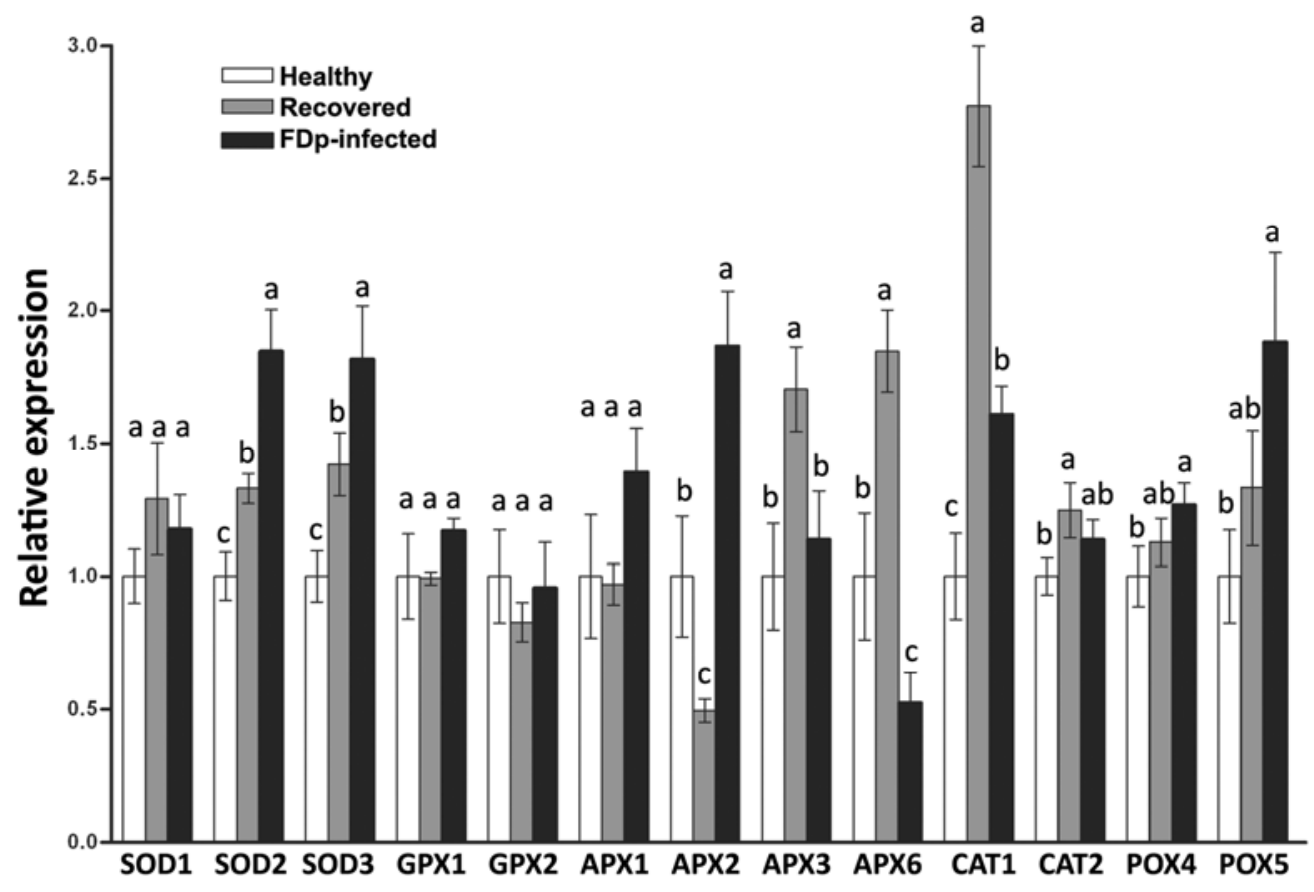

Fig. 3. Relative expression level of genes involved in hydrogen peroxide $\left(\mathrm{H}_{2} \mathrm{O}_{2}\right)$ scavenging in healthy $(\mathrm{H})$, recovered (R), and Flavescence dorée phytoplasma (FDp)-infected (I) 'Barbera' leaf midribs as determined by quantitative reverse-transcription polymerase chain reaction. Target genes were superoxide dismutase $(S O D)$, glutathione peroxidase $(G P X)$, ascorbate peroxidase $(A P X)$, catalase $(C A T)$, and peroxidase $(P O X)$. Data are presented as mean \pm standard error of two biological and three technical replicates $(n=6)$; for each gene, different letters denote significant differences at $P \leq 0.05$. 
genic peroxidase-coupled assay, we detected $\mathrm{H}_{2} \mathrm{O}_{2}$ also in healthy and FDp-infected midribs, with a content of 50 to $100 \mathrm{nmol} / \mathrm{g}$ FW, data consistent with the range detected in Arabidopsis leaves (47). Enhanced synthesis rather than the decreased scavenging might be the likely cause of the increased $\mathrm{H}_{2} \mathrm{O}_{2}$ level in 'Barbera' plants recovering from $\mathrm{FDp}$ infection. $\mathrm{R}$ grapevine plants seem to be able to achieve $\mathrm{H}_{2} \mathrm{O}_{2}$ accumulation essentially through an upregulation of genes involved in the production of $\mathrm{H}_{2} \mathrm{O}_{2}$, such as $G O X, G L P$, and $A C X$, even if some scavenging genes ( $A P X 3$, $A P X 6$, and $C A T 1$ ) were also induced. Conversely, the low levels of $\mathrm{H}_{2} \mathrm{O}_{2}$ detected in I plants might be linked to the activation of some scavenging genes, such as $A P X$ and $P O X$, without the induction of genes responsible for $\mathrm{H}_{2} \mathrm{O}_{2}$ production, with the exception of the slight transcriptional activation of $S O D$. Our results are partially in agreement with those reported by Musetti et al. (30): the activities of APX were found to be downregulated in their recovered plants, as well as the $A P X 2$ transcription in our results. This behavior has also been recently confirmed by proteomic analysis of recovered 'Barbera' grapevines (25), thus supporting a downregulation of APX. However, the modulation of other APX and $C A T$ genes is in partial contrast to what was reported by Musetti et al. (30): this may be explained by a differential regulation of some $A P X$ and $C A T$ isoforms. In addition, we can not exclude differential gene regulation among different grapevine cultivars, because Landi and Romanazzi (18) reported a cultivar effect on gene expression in $\mathrm{BNp}$-infected grapevines. The GLP family is a large and considerably heterogeneous group of proteins, which have been demonstrated to have oxalate oxidase (51) or superoxide dismutase (6) activity, resulting in the production of $\mathrm{H}_{2} \mathrm{O}_{2}$. GLP transcription in grapevine appears to correlate with defense response against Erysiphe necator (14) and with the early cessation of Uncinula necator development (8). In addition, GLP3 could be considered as an indicator of resistance to $U$. necator, because the gene was induced when resistant berries were inoculated; however, its expression was absent following inoculation of susceptible berries (8). The upregulation of GLP genes in $\mathrm{R}$ grapevines seem to correlate the defense response of these genes to the presence of the recovery phenomenon.

$\mathrm{R}$ and I grapevines did not show the upregulation of several genes of the AsA-GSH cycle, a typical response aimed to reduce the deleterious effects of oxidative stress in plants. However, $\gamma$ $E C S$, the gene that regulates the synthesis of GSH in plants, was upregulated in I grapevines, whereas $G S H-S$ (which was upregulated in $\mathrm{R}$ plants) did not seem to have a direct influence on GSH synthesis (36). The increase of GSH in I plants increases the substrate availability for GST enzymes and changes the redox state of the cells inducing a defense response; this may have induced the observed upregulation of several $P R$ genes. GST activity is induced in different plants by virus, fungal infection, or fungal elicitors. Valtaud et al. (45) reported that GST expression was greater in asymptomatic leaves of grapevine canes attacked by esca, while their mRNAs were less abundant once the disease became established. The induction of GST was only transient and was reduced when the tissues became overwhelmed by fungal toxins (45). The upregulation of GST2 in R grapevines could have a role in hindering the diffusion of phytoplasma in the cells of the grapevine leaf.

Defense responses in FDp-recovered grapevines. The direct link between ROS and SA-induced SAR has been hypothesized, leading to activation of various presumed defense effectors, including $P R$ genes (13). Surprisingly, despite the high amounts of $\mathrm{H}_{2} \mathrm{O}_{2}$ in $\mathrm{R}$ tissues in comparison with $\mathrm{I}$ ones, we observed the upregulation of several $P R$ genes ( $P R-1, B G L 2$ [PR-2], and THAU1 [PR-5]) in I grapevines only. The induction of THAU and $B G L$ in I plants confirmed previous observations by Margaria and Palmano (26) on FDp-infected grapevines, and by several authors $(1,16,18,40)$ on BNp-infected plants. The upregulation of $B G L 2$ in I plants can be associated with callose degradation aimed at facilitating phytoplasma spread through the plant whereas, in $\mathrm{R}$ plants, the lack of increase of its transcription might reflect the callose deposition, as observed in BNp-grapevine interactions $(16,18)$. The induction of these $P R$ genes could be a generic response against pathogen attack rather than an effective defense against the phytoplasma, as also reported in grapevine infected by U. necator (8).

NPRl genes are key positive regulators of the SA-dependent signaling pathway and are required for the transduction of the SA signal to activate PR expression and SAR (20). We did not observe significant changes in transcript levels of NPRl.1 and NPR1.2. However, Le Henanff et al. (20) observed that, in

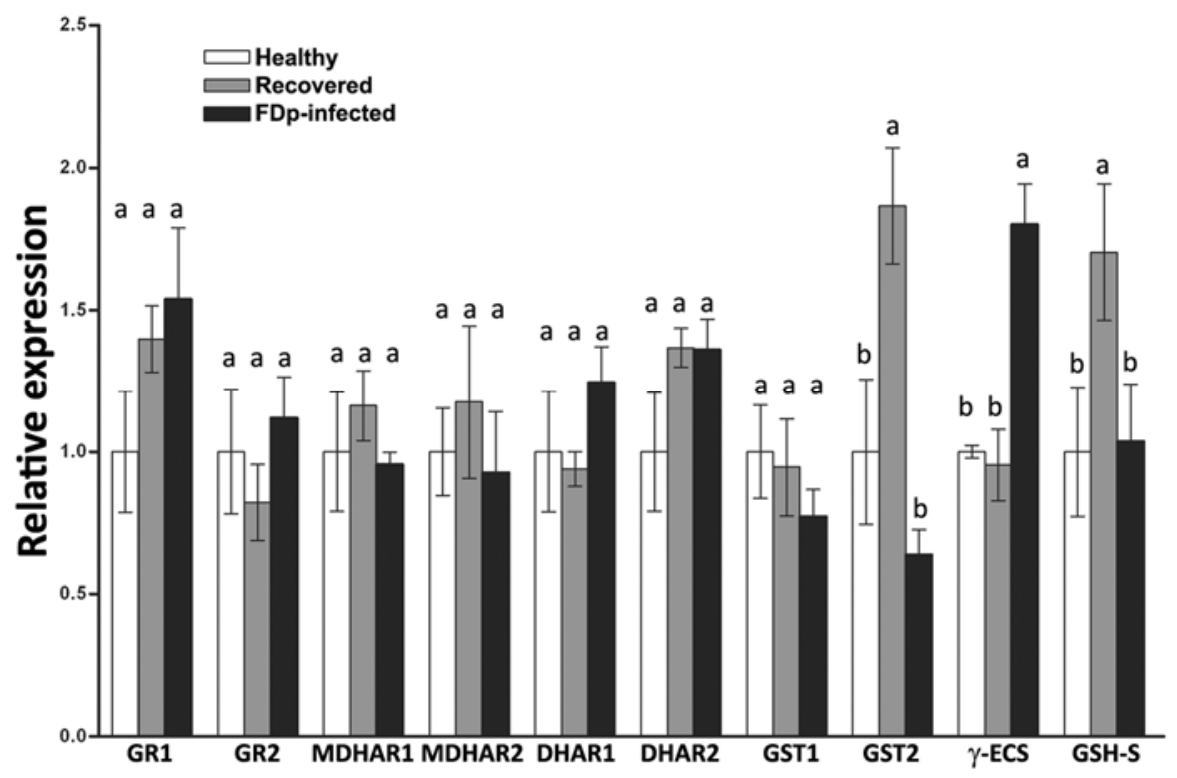

Fig. 4. Relative expression level of genes involved in ascorbate-glutathione cycle in healthy (H), recovered (R), and Flavescence dorée phytoplasma (FDp)infected (I) 'Barbera' leaf midribs as determined by quantitative reverse-transcription polymerase chain reaction. Target genes were glutathione reductase $(G R)$, monodehydroascorbate reductase $(M D H A R)$, dehydroascorbate reductase $(D H A R)$, glutathione S-transferase $(G S T)$, glutamylcysteine synthetase $(\gamma-E C S)$, and glutathione synthetase $(G S H-S)$. Data are presented as mean \pm standard error of two biological and three technical replicates $(n=6)$; for each gene, different letters denote significant differences at $P \leq 0.05$. 
grapevine, the NPR1.1 and NPR1.2 activity is regulated at the protein level, inducing $P R$ transcription in response to Plasmopara viticola infection.

Linked to transcriptional activation of $P R$ genes was the upregulation of WRKYI in I plants. WRKY DNA-binding proteins are transcription factors that have regulatory functions in plant defense responses to pathogen infection. They are characterized by a highly conserved-DNA region that binds a common promoter element contained in several SAR genes (23). The WRKY1 gene isolated from grapevine is upregulated by $\mathrm{SA}$ and $\mathrm{H}_{2} \mathrm{O}_{2}$, and when overexpressed in tobacco, induced a decrease in susceptibility toward some fungal pathogens (24). In contrast, another $W R K Y$ transcription factor isolated from grapevine, WRKY2, is not enhanced by any of these compounds. WRKY2 in tobacco did not lead to accumulation of the different $P R$ transcripts but reduced the susceptibility of transgenic tobacco to fungal pathogens such as Botrytis cinerea, Pythium spp., and Alternaria tenuis (34). The upregulation of WRKY2 in $\mathrm{R}$ grapevines could be an indication that the maintenance of the recovery conditions is independent of PR induction and not regulated by SA. In addition, Guillaumie et al. (15) showed that WRKY2 plays a role in lignin biosynthesis and xylem development. These authors hypothesize that the overexpression of WRKY2 in grapevine could limit the colonization of vineyards by $S$. titanus, vector of FDp, similar to what happens in rice, where plants overexpressing the $W R K Y$ gene showed enhanced tolerance to Sogatella furcifera due to increased lignification of stems (49). This hypothesis is intriguing, because the importance of the recovery phenomenon is strictly related to its stability over the years as well as to a hypothetical lower susceptibility of FDp-recovered plants to a reinfection.

FDp causes an alteration of biosynthesis of hormones in plants. The role of ABA in plant defense is controversial: in some cases, $\mathrm{ABA}$ behaves as a negative regulator of disease resistance whereas, in other plant-pathogen interactions, it activates the defense responses (7). The strong activation of NCED only in I plants could be linked to a senescence phenomenon in symptomatic leaf midribs rather than to a resistance response. JA biosynthesis seems to decrease both in $\mathrm{R}$ and I plants with the downregulation of the $O P R$ gene, confirming previous observations in which some phytoplasma effectors suppressed the JA-mediated defense and the JA biosynthesis (42). Instead, the increase of ACO transcripts in $\mathrm{R}$ tissues might indicate that the maintenance of the recovery state could be related to the activation of a defense response connected to ET signaling. The link between ET and $\mathrm{H}_{2} \mathrm{O}_{2}$ in grapevine has been recently demonstrated by Vergara et al. (48). These authors showed that ET and $\mathrm{H}_{2} \mathrm{O}_{2}$ act as signaling molecules in the response of grapevine buds to hypoxia, inducing the expression of the same antioxidant genes (APX, GPX, CAT, and $S O D)$.

In conclusion, we report that FDp-recovered 'Barbera' tissues accumulated $\mathrm{H}_{2} \mathrm{O}_{2}$ because of the transcriptional activation of genes involved in the production of $\mathrm{H}_{2} \mathrm{O}_{2}(G O X$ and GLP) and the downregulation of a gene coding for $\mathrm{H}_{2} \mathrm{O}_{2}$ scavenging (APX2). The recovery state seems to be maintained without the activation of defense genes linked to SA signaling but, probably, with the involvement of ET signaling and other defense responses (WRKY2). The upregulation of genes related to SA-mediated response in FDp-infected plants indicates that the grapevine reacts to the phytoplasma through SA-mediated signaling and JA repression, even though these responses do not appear to be effective in inducing a resistance against the FDp. Deeper analyses of physiological and molecular relationships between FDp and grapevine in the first phases of recovery establishment will help in understanding the triggering and maintenance of the recovery phenomenon. This information will be of great value, taking into account the growing importance of recovery in the field management of the disease.

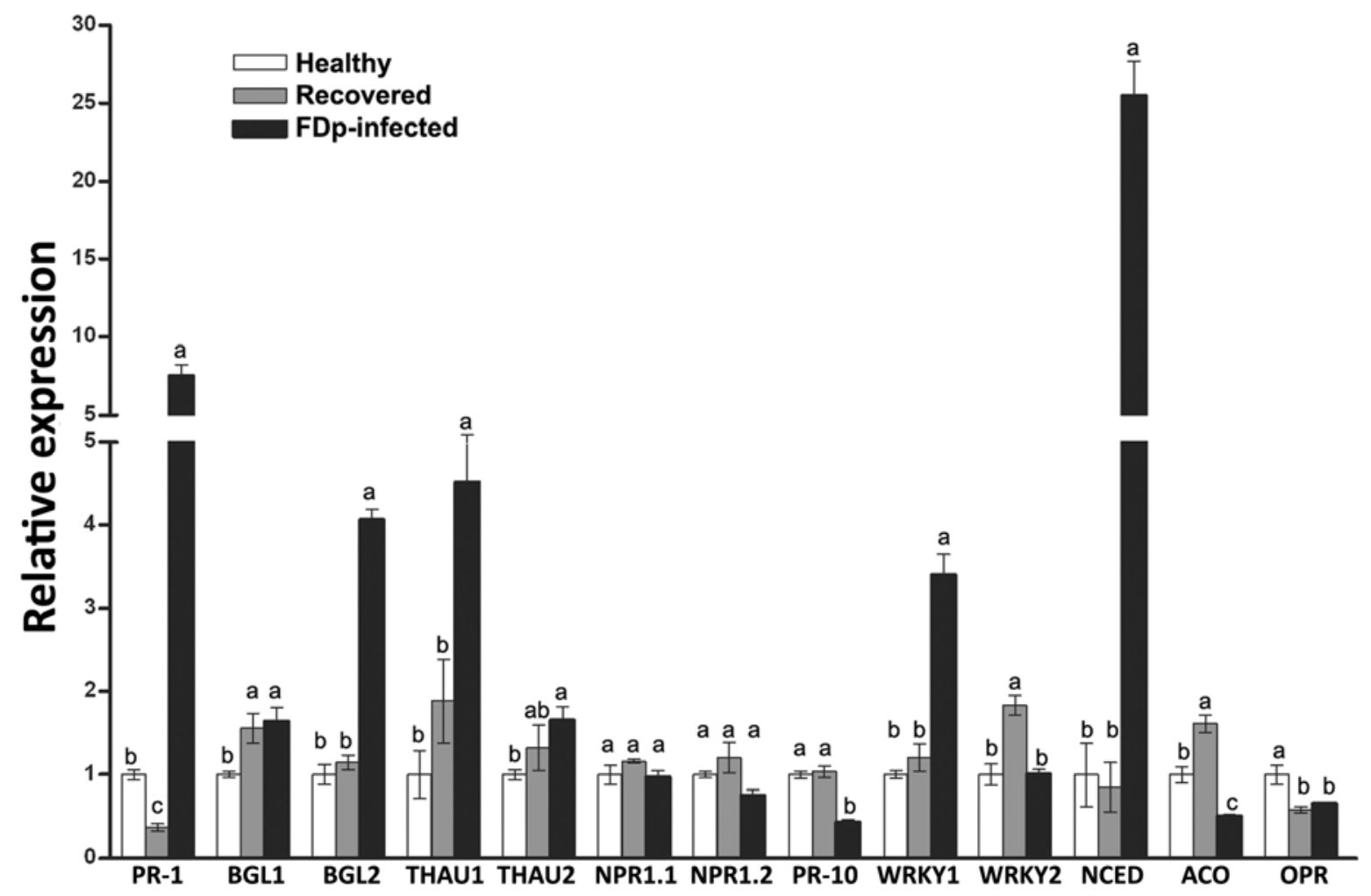

Fig. 5. Relative expression level of genes involved in defense responses and hormone biosynthesis in healthy $(\mathrm{H})$, recovered $(\mathrm{R})$, and Flavescence dorée phytoplasma (FDp)-infected (I) 'Barbera' leaf midribs as determined by quantitative reverse-transcription polymerase chain reaction. Target genes were pathogenesis-related $(P R)$ gene 1 (PR-1), $\beta$ 1-3 glucanase $(B G L)$, thaumatin-like protein (THAU), nonexpressor of PR.-1 gene (NPR1), PR-10, WRKY, 9-cis-epoxycarotenoid dioxygenase $(N C E D)$, 1-aminocyclopropane-1-carboxylate oxidase $(A C O)$, and 12-oxophytodienoate reductase 2-like $(O P R)$. Data are presented as mean \pm standard error of two biological and three technical replicates $(n=6)$; for each gene, different letters denote significant differences at $P \leq 0.05$. 


\section{ACKNOWLEDGMENTS}

This research was funded by Regione Piemonte, Project "FLADO, Studi sui fattori che favoriscono le epidemie di Flavescenza dorata in Piemonte e loro superamento."

\section{LITERATURE CITED}

1. Albertazzi, G., Milc, J., Caffagni, A., Francia, E., Roncaglia, E., Ferrari, F., Tagliafico, E., Stefani, E., and Pecchioni, N. 2009. Gene expression in grapevine cultivars in response to Bois Noir phytoplasma infection. Plant Sci. 176:792-804.

2. Angelini, E., Clair, D., Borgo, M., Bertaccini, A., and Boudon-Padieu, E. 2001. Flavescence dorée in France and Italy-occurrence of closely related phytoplasma isolates and their near relationships to Palatinate grapevine yellows and an alder yellows phytoplasma. Vitis 40:79-86.

3. Carraro, L., Ermacora, P., Loi, N., and Osler, R. 2004. The recovery phenomenon in apple proliferation-infected apple trees. J. Plant Pathol. $86: 141-146$.

4. Carvalho, L. C., Vilela, B. J., Vidigal, P., Mullineaux, P. M., and Amâncio, S. 2006. Activation of the ascorbate-glutathione cycle is an early response of micropropagated Vitis vinifera L. explants transferred to ex vitro. Int. J. Plant Sci. 167:759-770.

5. Caudwell, A. 1961. Les phénoménes de rétablissement chez la Flavescence dorée de la vigne. Ann. Epiphyt. 12:347-354.

6. Christensen, A. B., Thordal-Christensen, H., Zimmermann, G., Gjetting, T., Lyngkjær, M. F., Dudler, R., and Schweizer, P. 2004. The germin-like protein GLP4 exhibits superoxide dismutase activity and is an important component of quantitative resistance in wheat and barley. Mol. PlantMicrobe Interact. 17:109-117.

7. De Vleesschauwer, D., Yang, Y. N., Cruz, C. V., and Höfte, M. 2010. Abscisic acid-induced resistance against the brown spot pathogen Cochliobolus miyabeanus in rice involves MAP kinase-mediated repression of ethylene signaling. Plant Physiol. 152:2036-2052.

8. Ficke, A., Gadoury, D. M., Seem, R. C., Godfrey, D., and Dry, I. B. 2004. Host barriers and responses to Uncinula necator in developing grape berries. Phytopathology 94:438-445.

9. Foyer, C., and Noctor, G. 2005. Oxidant and antioxidant signalling in plants: a re-evaluation of the concept of oxidative stress in a physiological context. Plant Cell Environ. 28:1056-1071.

10. Gambino, G., Cuozzo, D., Fasoli, M., Pagliarani, C., Vitali, M., Boccacci, P., Pezzotti, M., and Mannini, F. 2012. Co-evolution between Grapevine rupestris stem pitting-associated virus and Vitis vinifera L. leads to decreased defence responses and increased transcription of genes related to photosynthesis. J. Exp. Bot. 63:5319-5333.

11. Gambino, G., and Gribaudo, I. 2006. Simultaneous detection of nine grapevine viruses by multiplex RT-PCR with coamplification of a plant RNA internal control. Phytopathology 96:1223-1229.

12. Gambino, G., Perrone, I., and Gribaudo, I. 2008. A rapid and effective method for RNA extraction from different tissues of grapevine and other woody plants. Phytochem. Anal. 19:520-525.

13. Glazebrook, J. 2005. Contrasting mechanisms of defense against biotrophic and necrotrophic pathogens. Annu. Rev. Phytopathol. 43:205-227.

14. Godfrey, D., Able, A. J., and Dry, I. B. 2007. Induction of a grapevine germin-like protein ( $V v G L P 3)$ gene is closely linked to the site of Erysiphe necator infection: a possible role in defence. Mol. PlantMicrobe Interact. 20:1112-1125.

15. Guillaumie, S., Mzid, R., Méchin, V., Léon, C., Hichri, I., Destrac-Irvine, A., Trossat-Magnin, C., Delrot, S., and Lauvergeat, V. 2010. The grapevine transcription factor WRKY2 influences the lignin pathway and xylem development in tobacco. Plant Mol. Biol. 72:215-234.

16. Hren, M., Nikolíc, P., Rotter, A., Blejec, A., Terrier, N., Ravnikar, M., Dermastia, M., and Gruden, K. 2009. 'Bois noir' phytoplasma induces significant reprogramming of the leaf transcriptome in the field grown grapevine. BMC Genomics 10:460.

17. Jaillon, O., Aury, J. M., Noel, B., Policriti, A., Clepet, C., Casagrande, A., Choisne, N., Aubourg, S., Vitulo, N., Jubin, C., Vezzi, A., Legeai, F., Hugueney, P., Dasilva, C., Horner, D., Mica, E., Jublot, D., Poulain, J., Bruyère, C., Billault, A., Segurens, B., Gouyvenoux, M., Ugarte, E., Cattonaro, F., Anthouard, V., Vico, V., Del Fabbro, C., Alaux, M., Di Gaspero, G., Dumas, V., Felice, N., Paillard, S., Juman, I., Moroldo, M., Scalabrin, S., Canaguier, A., Le Clainche, I., Malacrida, G., Durand, E., Pesole, G., Laucou, V., Chatelet, P., Merdinoglu, D., Delledonne, M., Pezzotti, M., Lecharny, A., Scarpelli, C., Artiguenave, F., Pè, M. E., Valle, G., Morgante, M., Caboche, M., Adam-Blondon, A. F., Weissenbach, J., Quétier, F., and Wincker, P. 2007. The grapevine genome sequence suggests ancestral hexaploidization in major angiosperm phyla. Nature 449:463-468.

18. Landi, L., and Romanazzi, G. 2011. Seasonal variation of defense-related gene expression in leaves from Bois Noir affected and recovered grapevines. J. Agric. Food Chem. 59:6628-6637.

19. Lee, I. M., Davis, R. E., and Gundersen-Rindal, D. E. 2000. Phytoplasma: Phytopathogenic mollicutes. Annu. Rev. Microbiol. 54:221-255.

20. Le Henanff, G., Heitz, T., Mestre, P., Mutterer, J., Walter, B., and Chong, J. 2009. Characterization of Vitis vinifera NPR1 homologs involved in the regulation of pathogenesis-related gene expression. BMC Plant Biol. 9:54.

21. Li, Z. T., Dhekney, S. A., and Gray, D. J. 2011. PR-1 gene family of grapevine: A uniquely duplicated PR-1 gene from a Vitis interspecific hybrid confers high level resistance to bacterial disease in transgenic tobacco. Plant Cell Rep. 30:1-11.

22. Maixner, M. 2006. Grapevine Yellows: Current development and unsolved questions. Pages 86-93 in: XV ICVG Meet. Ext. Abstr. Stellenbosch, South Africa.

23. Maleck, K., Levine, A., Eulgem, T., Morgen, A., Schmid, J., Lawton, K., Dangl, J. L., and Dietrich, R. A. 2000. The transcriptome of Arabidopsis thaliana during systemic acquired resistance. Nat. Genet. 26:403-410.

24. Marchive, C., Mzid, R., Deluc, L., Barrieu, F., Pirello, J., Gauthier, A., Corio-Costet, M. F., Regad, F., Cailleteau, B., Hamdi, S., and Lauvergeat, V. 2007. Isolation and characterization of a Vitis vinifera transcription factor, VvWRKY1, and its effect on responses to fungal pathogens in transgenic tobacco plants. J. Exp. Bot. 58:1999-2010.

25. Margaria, P., Abbà, S., and Palmano, S. 2013. Novel aspects of grapevine response to phytoplasma infection investigated by a proteomic and phospho-proteomic approach with data integration into functional networks . BMC Genomics 14:38.

26. Margaria, P., and Palmano, S. 2011. Response of the Vitis vinifera L. cv. 'Nebbiolo' proteome to Flavescence dorée phytoplasma infection. Proteomics 11:212-224.

27. Margaria, P., Turina, M., and Palmano, S. 2009. Detection of Flavescence dorée and Bois noir phytoplasmas, Grapevine leafroll associated virus-1 and -3 and Grapevine virus $A$ from the same crude extract by reverse transcription-realtime Taqman assays. Plant Pathol. 58:838-845.

28. Martini, M., Murari, E., Mori, N., and Bertaccini, A. 1999. Identification and epidemic distribution of two Flavescence dorée-related phytoplasmas in Veneto (Italy). Plant Dis. 83:925-930.

29. Morone, C., Boveri, M., Giosuè, S., Gotta, P., Rossi, V., Scapin, I., and Marzachì, C. 2007. Epidemiology of Flavescence dorée in vineyards in Northwestern Italy. Phytopathology 97:1422-1427.

30. Musetti, R., Marabottini, R., Badiani, M., Martini, M., Sanità di Toppi, L., Borselli, S., Borgo, M., and Osler, R. 2007. On the role of $\mathrm{H}_{2} \mathrm{O}_{2}$ in the recovery of grapevine (Vitis vinifera, cv. Prosecco) from Flavescence dorée disease. Funct. Plant Biol. 34:750-758.

31. Musetti, R. Paolacci, A., Ciaffi, M. Tanzarella, Tanzarella, O. A., Polizzotto, R., Tubaro, F., Mizzau, M., Ermacora, P., Badiani, M., and Osler, R. 2010. Phloem cytochemical modification and gene expression following the recovery of apple plants from Apple Proliferation disease. Phytopathology 100:390-399.

32. Musetti, R., Sanità di Toppi, L., Ermacora, P., and Favali, M. A. 2004. Recovery in apple trees infected with the apple proliferation phytoplasma: an ultrastructural and biochemical study. Phytopathology 94:203-208.

33. Musetti, R., Sanità di Toppi, L., Martini, M., Ferrini, F., Loschi, A., and Favali, M. A. 2005. Hydrogen peroxide localization and antioxidant status in the recovery of apricot plants from European Stone Fruit Yellows. Eur. J. Plant Pathol. 112:53-61.

34. Mzid, R., Marchive, C., Blancard, D., Deluc, L., Barrieu, F., Corio-Costet, M. F., Drira, N., Hamdi, S., and Lauvergeat, V. 2007. Over-expression of VvWRKY2 in tobacco enhances broad resistance to necrotrophic fungal pathogens. Physiol. Plant. 131:434-447.

35. Neuefeind, T., Reinemer, P., and Bieseler, B. 1997. Plant glutathione Stransferases and herbicide detoxification. Biol. Chem. 378:199-205.

36. Noctor, G., Gomez, L., Vanacker, H., and Foyer C. H. 2002. Interactions between biosynthesis, compartmentation and transport in the control of glutathione homeostasis and signalling. J. Exp. Bot. 53:1283-1304.

37. Osler, R., Carraro, L., Loi, N., and Refatti E. 1993. Symptom expression and disease occurrence of a yellow disease of grapevine in Northern Italy. Plant Dis. 77:496-498.

38. Osler, R., Loi, N., Carraro, L., Musetti, R., Loschi, A., and Ermacora, P. 2004. Spontaneous recovery in grapevines affected by flavescence dorée phytoplasma. Acta Physiol. Plant. 26:134-134.

39. Romanazzi, G., and Murolo S. 2008. Partial uprooting and pulling to induce recovery in Bois noir infected grapevines. J. Phytopathol. 156:747750.

40. Santi, S., Grisan, S., Pierasco, A., De Marco, F., and Musetti R. 2013. Laser microdissection of grapevine leaf phloem infected by stolbur reveals site-specific gene responses associated to sucrose transport and metabolism. Plant Cell Environ. 36:343-355.

41. Slesak, I., Libik, M., Karpinska, B., Karpinski, S., and Miszalski, Z. 2007. The role of hydrogen peroxide in regulation of plant metabolism and 
cellular signalling in response to environmental stresses. Acta Biochim. Pol. 54:39-50.

42. Sugio, A., MacLean, A. M., Kingdom, H. N., Grieve, V. M., Manimekalai R, and Hogenhout, S. A. 2011. Diverse targets of phytoplasma effectors: From plant development to defense against insects. Annu. Rev. Phytopathol. 49:175-195.

43. Thomma, B. P., Eggermont, K., Penninckx, I. A., Mauch-Mani, B., Vogelsang, R., Cammue, B., and Broekaert, W. F. 1998. Separate jasmonate-dependent and salicylate-dependent defense response pathways in Arabidopsis are essential for resistance to distinct microbial pathogens. Proc. Natl. Acad. Sci. USA 95:15107-15111.

44. Truman, W., Bennett, M. H., Kubigsteltig, I., Turnbull, C., and Grant, M. 2007. Arabidopsis systemic immunity uses conserved defense signaling pathways and is mediated by jasmonates. Proc. Natl. Acad. Sci. USA 104:1075-1080.

45. Valtaud, C., Foyer, C. H., Flerat-Lessard, P., and Bourbouloux, A. 2009. Systemic effects on leaf glutathione metabolism and defence protein expression caused by esca infection in grapevines. Funct. Plant Biol. 36:260-279.

46. Velasco, R., Zharkikh, A., Troggio, M., Cartwright, D. A., Cestaro, A., Pruss, D., Pindo, M., FitzGerald, L. M., Vezzulli, S., Reid, J., Malacarne, G., Iliev, D., Coppola, G., Wardell, B., Micheletti, D., Macalma, T., Facci, M., Mitchell, J. T., Perazzolli, M., Eldredge, G., Gatto, P., Oyzerski, R., Moretto, M., Gutin, N., Stefanini, M., Chen, Y., Segala, C., Davenport, C.,
Dematte, L., Mraz, A., Battilana, J., Stormo, K., Costa, F., Tao, Q., SiAmmour, A., Harkins, T., Lackey, A., Perbost, C., Taillon, B., Stella, A., Solovyev, V., Fawcett, J. A., Sterck, L., Vandepoele, K., Grando, S. M., Toppo, S., Moser, C., Lanchbury, J., Bogden, R., Skolnick, M., Sgaramella, V., Bhatnagar, S. K., Fontana, P., Gutin, A., Van de Peer, Y., Salamini, F., and Viola, R. 2007. A high quality draft consensus sequence of the genome of a heterozygous grapevine variety. PloS ONE 2:e1326.

47. Veljovic-Jovanovic, S., Noctor, G., and Foyer, C. H. 2002. Are leaf hydrogen peroxide concentrations commonly overestimated? The potential influence of artefactual interference by tissue phenolics and ascorbate. Plant Physiol. Biochem. 40:501-507.

48. Vergara, R., Parada, F., Rubio, S., and Pérez, F. J. 2012. Hypoxia induces $\mathrm{H}_{2} \mathrm{O}_{2}$ production and activates antioxidant defence system in grapevine buds through mediation of $\mathrm{H}_{2} \mathrm{O}_{2}$ and ethylene. J. Exp. Bot. 63:4123-4131.

49. Wang, H., Hao, J., Chen, X., Hao, Z., Wang, X., Lou, Y., Peng, Y, and Guo, Z. 2007. Over-expression of rice WRKY89 enhances ultraviolet B tolerance and disease resistance in rice plants. Plant Mol. Biol. 65:799815.

50. Weintraub, P. G., and Beanland, L. 2006. Insect vectors of phytoplasmas. Annu. Rev. Entomol. 51:91-111.

51. Zhou, F., Zhang, Z., Gregersen, P. L., Mikkelsen, J. D., de Neergaard, E., Collinge, D. B., and Thordal-Christensen, H. 1998. Molecular characterization of the oxalate oxidase involved in the response of barley to the powdery mildew fungus. Plant Physiol. 117:33-41. 